\title{
Internal capital markets and capital structure: bank versus internal debt
}

\author{
Nico Dewaelheyns \\ Lessius University College, Department of Business Studies, Korte Nieuwstraat 33, 2000 Antwerp, Belgium \\ Katholieke Universiteit Leuven, Faculty of Business and Economics, Department of Accountancy, Finance and \\ Insurance, Naamsestraat 69, 3000 Leuven, Belgium \\ email: nico.dewaelheyns@econ.kuleuven.be \\ Cynthia Van Hulle \\ Katholieke Universiteit Leuven, Faculty of Business and Economics, Department of Accountancy, Finance and \\ Insurance, Naamsestraat 69, 3000 Leuven, Belgium \\ email: cynthia.vanhulle@econ.kuleuven.be
}

\begin{abstract}
We argue that domestic business groups are able to actively optimize the internal/external debt mix across their subsidiaries. Novel to the literature, we use bi-level data (i.e. data from both individual subsidiary financial statements and consolidated group level financial statements) to model the bank and internal debt concentration of non-financial Belgian private business group affiliates. As a benchmark, we construct a size and industry matched sample of non-group affiliated (stand-alone) companies. We find support for a pecking order of internal debt over bank debt at the subsidiary level which leads to a substantially lower bank debt concentration for group affiliates as compared to standalone companies. The internal debt concentration of a subsidiary is mainly driven by the characteristics of the group's internal capital market. The larger its available resources, the more intragroup debt is used while bank debt financing at the subsidiary level decreases. However, as the group's overall debt level mounts, groups increasingly locate bank borrowing in subsidiaries with low costs of external financing (i.e. large subsidiaries with important collateral assets) to limit moral hazard and dissipative costs. Overall, our results are consistent with the existence of a complex group wide optimization process of financing costs.
\end{abstract}

\section{Keywords: Internal Capital Markets; Capital Structure; Debt Source Concentration; Ownership Structure; Bank Debt}

JEL - Classification Codes: G32, G21

\footnotetext{
Acknowledgements - We would like to thank Marco Becht, Marc Deloof, Dirk Heremans, Nancy Huyghebaert, Frederiek Schoubben, Linda Van de Gucht, an anonymous referee and the Managing Editor (John Doukas) for useful comments and suggestions.

(Corresponding author: Nico Dewaelheyns)
} 


\section{Introduction}

During the last decade, a growing number of theoretical and empirical studies have compared financing via internal capital markets of conglomerates, business groups or multinational corporations, with external market finance. Contrary to the case of the conglomerates described in the theoretical literature, where external financing is often assumed to be raised by headquarters and passed through to divisions (e.g. Gertner et al., 1994; Stein, 1997), in practice member firms of business groups and multinationals are often separate legal entities which may also directly access the external capital markets. Within these types of organizations, the external/internal financing decision is likely to be a complex group wide trade-off between benefits and costs of internal and external financing. Empirical evidence of this phenomenon is found by Desai et al. (2004), who show that foreign affiliates of US multinational corporations use parent debt as a substitute for external debt, especially in countries where access to external financing is limited or expensive. They argue that the possibility of raising debt where it is cheapest and the potential for tax arbitrage offers multinational corporations an important advantage over their local competitors. However, many large domestic firms are also tied together through ownership to form a domestic group. Especially in Continental Europe, South East Asia and several emerging market regions (e.g. India) this group organizational form is important. For instance, almost one third of the top 100,000 non-financial companies in the Eurozone have domestic group ties. ${ }^{1}$ The vast majority of these groups does not have a stock exchange quoted component.

This paper evaluates whether, as with international groups, domestic groups can offer their subsidiaries important financing advantages as well. Our contributions to the literature, which are discussed in more detail below, can be summarized as follows: (a) we explicitly focus on private domestic groups, an important organizational form for which very little empirical evidence is available so far; (b) this focus enables us to develop relatively clean 
hypotheses and tests for the two main financing sources for this type of company: internal debt and bank debt; (c) novel to the literature, we include data from multiple financial statements (at subsidiary and at consolidated group level) which leads to a more complete picture of the debt source mix decision; (d) next to separate debt source concentration models, we also estimate a system of equations to capture the simultaneity of the bank debt and internal debt concentration decision; (e) as we compare with stand-alone companies we can pinpoint the impact of group membership on bank debt concentration.

To ensure clean testing we examine the capital structure of large domestic subsidiaries of Belgian private business groups. ${ }^{2}$ First, this implies that all companies we consider operate under the same tax regime and within the same institutional framework. Second, confounding effects are further reduced because of the limits on financing alternatives imposed by the private nature of the groups: external financing will almost always be bank debt. ${ }^{3}$ Finally, only larger subsidiaries have an obligation to report detailed information on internal debt financing. ${ }^{4}$ Limiting ourselves to this type of affiliate has the additional advantage that effects from typical financing problems of small firms are avoided within the sample. ${ }^{5}$ Within this setting, we contribute to the literature by developing testable hypotheses about the nature of the choice between both sources of funding. Using a sample of 553 subsidiaries which are part of 253 different business groups, we model the determinants of the bank and internal debt concentration (i.e. the importance of bank and internal debt as a fraction of total liabilities). As mentioned above, we use information from multiple financial statements (at company level and at consolidated group level), which allows us to investigate the importance of affiliate versus group characteristics. Moreover, we use a sample of comparable stand-alone firms as a benchmark to pinpoint the impact of group membership on bank debt concentration. 
Our focus is different from that of most of the empirical literature on business groups' internal capital markets, which is mainly concerned with explaining the general leverage level of group firms. As a by-product, this literature does offer some inferences on the use of external debt by subsidiaries. Manos et al. (2001) demonstrate that group issues matter in determining the leverage levels of quoted Indian firms. Bianco and Nicodano (2006) show that in Italian business groups, subsidiaries use less external debt as compared to the group holding company. Verschueren and Deloof (2006) find similar results for large Belgian firms and conclude that internal debt is a substitute for external debt. Direct empirical evidence on the drivers of the different components of debt taken on by subsidiaries is scarce. An exception to this is the case of Japanese keiretsu (e.g. Hoshi et al., 1990; Hoshi et al., 1993; Gul, 1999). However, due to the presence of group banks the keiretsu capital structure problem is unique (e.g. bank debt and internal debt can often not be distinguished).

The empirical aim of our study is also different from that of most of the general capital structure literature, which either concerns the choice between public debt and equity (Marsh, 1982; Easterwood and Kadapakkam, 1991; Shyam-Sunder and Myers, 1999; Gaud et al., 2005, among many others - see Myers, 2001 for a survey), or public debt vs. private debt vs. equity (e.g. Houston and James, 1996; Johnson 1997, 1998; Hooks, 2003; Denis and Mihov, 2003). For companies without access to public debt or equity, the key financing decision concerns the creation of an optimal mix of different private debt types. As argued above, for private business group affiliates in a bank-based financial system, the most important dimension of the debt source decision is likely to be the choice between bank and internal debt.

Previewing our main results, we find evidence suggesting that cost savings from centralising financing within groups are an important driver of internal debt use by subsidiaries. Moreover, as group size, age and profitability increase, bank debt at the 
subsidiary level is replaced by internal debt. However, this preference for internal financing decreases with group leverage. Contrary to the relative use of internal debt, which is mainly driven by the characteristics of the internal capital market (cf. Section 5.2), individual subsidiary characteristics play a more important role in explaining bank debt concentration (cf. Section 5.1). Most importantly, using a system of simultaneous equations, we find that internal debt has a strong negative impact on bank borrowing by subsidiaries, while, in reverse, bank borrowing does not shape internal debt concentration (cf. Section 5.3). The data therefore indicate that groups use a pecking order in favour of internal financing. Also, as compared to stand-alone firms, where cash flow shortages often have to be filled with bank debt, in subsidiaries this role is largely taken over by internal debt. Nevertheless, we find evidence indicating that, if needed, groups can facilitate access to bank borrowing by their subsidiaries by adding internal debt, as in practice the latter is subordinated to bank debt. Furthermore our results suggest that as groups use more leverage, moral hazard and dissipative costs from centralizing external borrowing increase. Groups tend to solve this problem by placing bank debt within subsidiaries and hence offer banks seniority rights on the assets of these affiliates. Overall, the evidence consistently supports the notion that the optimisation of group-wide financing costs is an important driver of domestic group subsidiaries' financing choices.

The remainder of the paper is organized as follows. Section 2 develops a general perspective on the advantages and disadvantages of bank and internal debt and formulates several hypotheses. Section 3 links this perspective with specific firm level and group level variables. The sample and univariate statistics are discussed in Section 4 . Section 5 contains the empirical analysis and Section 6 discusses robustness issues. Finally, Section 7 summarizes the main conclusions. 


\section{Internal capital markets and the costs and benefits of bank and internal debt: hypotheses}

The literature on internal capital markets often takes the view that the process of attracting and assigning financial resources throughout the group is driven by group-wide cost optimisation (e.g. Gertner et al., 1994; Stein, 1997; Schiantarelli and Sembenelli, 2000; Bianco and Nicodano, 2006). It is also well known that in practice, treasury and overall financial planning in most large business groups is dominated by pooling systems to save on costs. ${ }^{6}$ This is in line with Coase's theorem which implies that rational agents (in this case bank, parent and subsidiary) negotiate towards an equilibrium where dissipative costs (i.e. moral hazard, bankruptcy costs, etc.) are minimised. Based on theoretical and empirical evidence, we will argue that if internal capital markets are actively used, and a process of group-wide optimisation w.r.t. the choice between internal debt and bank debt occurs, the hypotheses discussed below are likely to hold.

H1. There is a pecking order of internal debt over external bank debt in business group subsidiaries.

The pecking order logic follows from the fact that theoretical research implies that internal debt may often have important cost advantages over external debt sources such as bank debt. First, internal debt is owner-provided. Gertner et al. (1994) and Stein (1997) argue that this leads to a more efficient allocation of resources and reduced monitoring costs thanks to lower asymmetric information. Second, because of its owner-provided nature, internal debt is very flexible and can easily be renegotiated at low or zero costs (Hoshi et al., 1990). Third, it entails fewer moral hazard problems and avoids conflicts of interest between the parent and the subsidiary's debt holders. Put differently, internal borrowing avoids costs linked to the possibility of tunnelling (Bianco and Nicodano, 2006), i.e. reducing the value of the subsidiary at the expense of external debt holders (cf. Buysschaert et al., 2004). Empirical evidence on the relative costs of internal and external debt is scarce. Desai et al. (2004) 
document that the use of external debt decreases with interest rates while the use of internal debt increases, implying that more expensive external debt is being replaced by cheaper internal debt financing. Obviously, this relative cost advantage will not be the same in all cases, which leads to hypotheses $\mathrm{H} 2$ and $\mathrm{H} 3$.

H2. Subsidiaries of financially weaker business groups will, ceteris paribus, use more bank debt.

Regardless of the advantages of internal debt outlined above, Verschueren and Deloof (2006), Manos et al. (2001) and Bianco and Nicodano (2006), among others, document that use of bank debt by subsidiaries remains substantial. However, this need not be at odds with group-wide cost optimization, as the literature also suggests some potential advantages to the use of bank debt at subsidiary level. One reason why groups may prefer some of their subsidiaries to use bank debt is the reduction of costs of financial distress. By placing external (bank) debt at the subsidiary level, the group reduces bankruptcy costs because the limited liability of the subsidiary decreases the risk of propagation of financial problems throughout the group. As a business group subsidiary is a legally independent company with limited liability, the group can let it file for bankruptcy if the financial distress of the subsidiary becomes too severe, to save the rest of the group's activities (Bianco and Nicodano, 2006).7 Second, direct contracting of bank debt at the subsidiary level allows for collateralization which results in cost saving by reducing moral hazard problems (see e.g. Leeth and Scott, 1989). ${ }^{8}$ These arguments imply that bank borrowing by a subsidiary may become a useful tool to limit overall moral hazard costs as the group's overall leverage increases, as both limiting propagation of bankruptcy costs and offering creditors reduced exposure via collateralization will become more relevant. Lenders are likely to be especially aware of these issues as for the private groups studied in this paper, access to additional 
external equity is limited and group leverage likely makes up for the shortage of internally generated funds.

However, one could also argue that increasing group leverage fosters the use of internal debt to the detriment of bank financing in subsidiaries, i.e. the reverse of what is hypothesized above. For, due to potential economies of scale, one would expect that attracting bank financing would be centralized, and that afterwards these resources would be transferred to subsidiaries under the format of internal debt. As more bank debt is attracted, more resources are available for transfer. Although the logic of cost savings through the internal capital market as well as empirical evidence on relative debt levels in parent and subsidiaries (e.g. Bianco and Nicodano (2006) show that relative debt levels in group holding companies tend to be higher than those in subsidiaries) suggest that such transfers take place, it does not explain why groups seem to forgo savings by making substantial use of bank debt within subsidiaries. The reason is that this line of argument does not take into account the two advantages of direct bank borrowing discussed above (viz. limiting the propagation of bankruptcy costs throughout the group and collateralization of subsidiary assets) which are likely to increase in importance as group leverage mounts. Nevertheless it remains an empirical question which effect dominates.

H3. Subsidiaries with more (less) difficulty in attracting external financing will, ceteris paribus, use more internal (bank) debt.

Insights from the literature suggest that subsidiary bank debt is mostly used by those affiliates for which the dissipative costs of external borrowing are relatively small. Desai et al. (2004) show that subsidiaries of multinational companies use more internal debt financing in countries where external financing is difficult or expensive to come by. Claessens et al. (2006) 
argue that group affiliation in general will be especially beneficial for those subsidiaries that would have more difficulty in attracting external financing at good rates. Ghatak and Kali's (2001) model shows that internal financing can provide a solution for companies who would otherwise face credit rationing by banks caused by asymmetric information. This idea is supported by Bond (2004) who shows that group financing is preferred above bank debt for high-risk, low-quality projects. ${ }^{9}$

\section{Group and subsidiary characteristics and affiliate use of bank and internal debt}

Our hypotheses have implications for the relationship between company and group level variables on the one hand and the debt source mix on the other. They allow us to model, both separately (see Sections 5.1 and 5.2 for results) and simultaneously (see Section 5.3), the determinants of bank debt and internal debt concentration. Simultaneous modelling will also allow us to empirically test for a pecking order in financing choices (hypothesis H1).

\subsection{Group characteristics and subsidiary bank and internal debt concentration}

Group size, age and profitability - The pecking order Hypothesis H1 - which as mentioned above will be tested by simultaneous estimation - implies that, as the resources available via the internal capital market augment, the use of internal debt (bank debt) in subsidiaries increases (decreases). Gertner et al. (1994), Stein (1997), Lamont (1997), Chang and Hong (2000) and Claessens et al. (2006), among others, show that larger, older and more profitable groups tend to have more such resources available.

Group leverage and reserves - The logic underlying hypothesis $\mathrm{H} 2$ implies that higher levels of group leverage induce subsidiaries to take on more bank debt, especially if higher group leverage reflects a shortage of internally generated funds. However, as also discussed in the 
previous Section, if increasing group leverage mainly reflects the information that headquarters or a financial subsidiary passes external financing through to affiliates, group leverage should instead have a positive impact on subsidiaries' internal debt use. Therefore, as an additional check on the interpretation of the empirical findings we also consider group reserves. In particular, if increasing group leverage reflects a shortage of internally generated funds - as we would expect in private groups - group reserves should be negatively related to group leverage and subsidiary bank debt concentration, but positively to internal debt use of affiliates.

\subsection{Individual firm characteristics and subsidiary bank and internal debt concentration}

The discussion underlying hypothesis H3 suggests that subsidiaries that actively use bank debt are likely to have characteristics similar to those of stand-alone companies that also easily obtain this type of financing. The main drivers of bank debt in stand-alone firms found in the literature are discussed below. ${ }^{10}$ The arguments easily transfer to bank debt use by affiliates. Only a few adjustments are needed to make them applicable to internal debt concentration as well. The latter are summarized at the end of this Section.

Profitability - The findings of, for instance, Smith (1987) and Carey et al. (1998) imply that low profitability may lead to credit rationing by banks, and therefore to a positive relationship between profitability and bank debt use. Conversely, private companies may attract additional bank debt to fill (temporary) cash shortages caused by low profitability, if banks have a competitive advantage in rendering valuable monitoring services (Diamond, 1984, 1991; Fama, 1985; Ramakrishnan and Thakor, 1984; among others).

Tangibility - When private stand-alone firms use tangible assets as collateral, they reduce the cost of bank loans by limiting exposure and asset-substitution problems (Myers and Majluf, 
1984; Detragiache, 1994; Boot et al., 1991; Leeth and Scott, 1989; among others). Consequently higher levels of tangibility would imply more bank debt, ceteris paribus. ${ }^{11}$

Size - Ceteris paribus, larger private stand-alone firms have lower costs of financial distress (Rajan and Zingales, 1995), and are less likely to engage in asset substitution activities that hurt debt holders. Larger companies are also more likely to have access to bank financing (Petersen and Rajan, 1994). Therefore, we predict a positive relationship between size and the concentration of bank debt. ${ }^{12}$

Age - The age of a stand-alone company is often regarded as a proxy for reputation. Older companies have a longer track-record and/or stronger reputation and should have better relationships with lenders, lowering the costs of debt. For public firms this may lead to more bank financing (Petersen and Rajan, 1997). By contrast, for private firms whose access to financing is usually limited to self financing and private debt, age may also be associated with availability of more internally generated funds, and hence a reduced need for bank debt (Hall et al., 2000).

Growth opportunities - Growth may enhance asymmetric information and moral hazard problems and overall strengthen unfavourable pressure arising from bank debt in standalone companies. ${ }^{13}$ Especially for private firms, debt servicing may enhance capital constraints. Conversely, as growth firms need more financial resources, one could argue that private companies with limited alternative financing sources may be forced to fill their extra needs through more bank debt.

Leverage - When, as mentioned above, banks have an advantage in offering valuable monitoring services over other forms of debt available to private firms, one would expect a 
positive relationship between the level of leverage and the importance of bank debt for stand-alone firms: relative to other forms of private debt, bank debt reduces asymmetric information and asset substitution problems, and hence allows for an ex ante higher level of leverage.

Given a few adjustments of the argument, most of the preceding determinants also apply to internal debt. Concerning profitability and internal financing, the models by, e.g., Ghatak and Kali (2001) or Bond (2004) discussed in the previous Section imply that the advantages of the owner provided nature of internal debt may turn it into an appropriate instrument to fill the extra cash needs of poorly performing group firms, thereby causing a negative relation between profitability and the use of internal debt. Because internal debt is owner provided, the reputation effect of age is unlikely to cause a positive relationship between age and the use of internal debt. By contrast, if older group firms have over time generated more internal funds, we would predict a negative relationship between age and internal financing. Internal debt may also be an appropriate instrument to finance growth needs (hence its use should be positively related to growth opportunities) and may increase with subsidiary leverage because of its superior capacity to reduce asymmetric information problems between lender and borrower (cf. Hoshi et al., 1990). Finally, as neither tangibility nor size has a clear link with the specific properties of internal debt, we cannot predict an a priori relationship with these variables.

\section{Sample and univariate statistics}

\subsection{Sample composition}

We start out from a data set containing externally audited accounting information on all private Belgian non-financial companies that file complete annual accounts ${ }^{14}$ for the fiscal 
years 1997 to 2002. These data were obtained from Bureau Van Dijk EP's BelFirst database. Using ownership and financial information from the same source, we construct two samples: one containing only stand-alone companies and another consisting of members of domestic non-financial business groups.

In our context, internal or intra-group debt is debt received from 'affiliated' companies. Under Belgian Accounting Law, all firms which are controlled by, or control a corporation, are considered to be affiliated. ${ }^{15}$ For the group sample, we select operating subsidiaries of non-financial private business groups filing both unconsolidated accounts at subsidiary level and consolidated accounts at the level of the group. ${ }^{16}$ A company is classified as a business group member if at least $50 \%$ of its shares are held (directly or indirectly) by the controlling company of the group. Because of the high level of control within Belgian business groups, setting a lower threshold (e.g. 20\%, cf. Gadhoum et al., 2005) would only have a marginal impact on the number of companies included. We exclude subsidiaries of groups which are controlled by foreign corporations or which are State controlled. Finally, to minimize the risk of classification errors, we only include a firm in the stand-alone sample if it has no dominant incorporated shareholder and if it uses no internal debt. We consider a dominant incorporated shareholder to be absent when the largest incorporated shareholder does not control more than $20 \%$ of the sample company, either through direct or indirect ownership.

Following common practice, we exclude companies with zero sales, firms with extremely high leverage levels ( $>100 \%$ of total assets) ${ }^{17}$ and several categories of service companies. Using the criteria described above, we construct a group sample of 553 companies (1,742 firm years) which are part of 253 different business groups and a standalone sample of 1,521 companies (5,679 firm years). Finally, to improve comparability, we 
select a one-to-one sub-sample of stand-alone companies that matches the industry and the size of the group sample firms as closely as possible. ${ }^{18,19}$ Table 1 shows the sample's industry composition. All major industries are included, with manufacturing and distribution being best represented, in line with the Belgian economy as a whole.

Table 1 about here

$* * * * * * * * * * * * * * * * * * * * * * * *$

\subsection{Univariate statistics}

For each firm year we compute standard proxies for the variables discussed in the hypotheses Section. Definitions are included in Table 2. Panel A of Table 3 contains summary statistics of the key variables. The left hand side of the Table reports medians for the standalone and group samples, and Mann-Whitney equality test statistics. The right hand side shows means and t-test statistics. Minimal and maximal values (left hand side) and standard deviations (right hand side) are reported in square brackets. To reduce the potential impact of outliers, all continuous explanatory variables have been winsorized at $1 \%$ and $99 \%$.

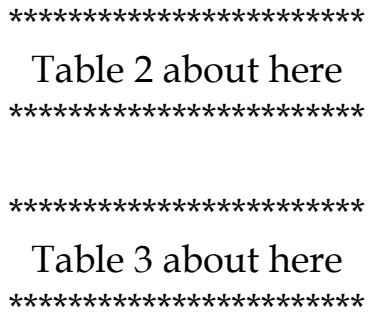

Most company level variables differ between stand-alone firms and subsidiaries. Stand-alone companies have a better median profitability (ROA) and use relatively more tangible assets (TANG). Even after matching, subsidiaries remain statistically larger (SIZE) than stand-alones, although from an economic perspective the difference is unlikely to be important (median total assets of 9.6 million euros for the stand-alone sample as compared to 13.1 million euros for the group sample). Concerning age (AGE), both samples contain 
mature companies, although those in the group sample are somewhat younger (median age of 23 years for the stand-alone and 19 years for the group sample). Subsidiaries have a lower growth rate (GROWTH) but a slightly higher level of leverage (LEV) as compared to standalone firms. ${ }^{20}$ However the difference in leverage is not statistically significant. Within the group sample, we observe that the median leverage of affiliates is $67 \%$, which is substantially higher than the median leverage of $63.7 \%$ at group level (GLEV). This is not surprising if the subsidiary uses internal debt - at least partly - as a substitute for external debt. In consolidated statements the internal debt is netted out, leaving only the business group's external debt. It is also interesting to note that, contrary to median subsidiary profitability, group level profitability (GROA) is comparable to the profitability of stand-alone firms. This could indicate that subsidiary profits are partially transferred to the parent or to financial group firms. Furthermore, the size of affiliates relative to the group to which they belong is relatively small: the ratio between subsidiary size (eSIzE) and group size (eGSIZE) is about $8 \% .{ }^{21}$

Stand-alone companies use more bank debt (BANK). Specifically, this form of financing only accounts for $11.76 \%$ of total liabilities within the group sample, while for the median stand-alone firm it amounts to $19.61 \%$. One reason for this important difference is the fact that fewer subsidiaries (i.e. 70.1\%) have bank debt outstanding as compared to standalone firms $(80.6 \%)$. The use of internal debt (INT) is another reason: with a median of $13.45 \%$ internal debt is more important than bank financing in group subsidiaries. Its use is also more widely spread (i.e. $84.6 \%$ ) as compared to bank debt. As to comparison with other studies, the importance of internal debt in our sample of private, domestic operating companies $(16.5 \%$ of total assets on average, median of $7.2 \%)$ is virtually identical to that of Verschueren and Deloof's (2006) sample of Belgian subsidiaries $(16.7 \%$ of total assets on average, median of $6.8 \%$ ), but is quite high compared to the situation in the foreign affiliates of US multinationals in Desai et al. (2004) (8\% of total assets on average, median $0.4 \%$ ) and 
the private Italian operating companies in quoted groups in Bianco and Nicodano (2006) $(9 \%$ of total assets on average, median $0 \%$ ). By contrast, the use of bank debt in Bianco and Nicodano's operating companies (13\% of total assets, median of $7 \%)$ is very close to that in our sample companies (14.5\% of total assets, median of $7.0 \%)$.

At group level, the relative importance of bank financing is much larger than for subsidiaries. In the median consolidated business group, bank debt makes up $32.44 \%$ of total debt while this only amounts to $11.76 \%$ for group subsidiaries. Almost all groups (i.e. $97.2 \%$ ) make use of this form of financing. Furthermore, bank borrowing at consolidated group level is higher than bank borrowing by stand-alones (i.e. $32.44 \%$ versus $19.61 \%$ ). Together with the importance of internal debt, this is consistent with the hypothesis that groups tend to centralize bank borrowing at the level of the parent and hand down these financial resources to subsidiaries under the form of internal debt. Preceding findings are confirmed by the means and, overall, are consistent with earlier findings in the literature ( $c f$. Bianco and Nicodano, 2006).

Panel B of Table 3 shows statistics for BANK, INT and LEV split up according to the level of group leverage, GLEV (i.e. subsidiaries belonging to a group which is among the $50 \%$ most (least) levered groups in our sample). On average, subsidiaries of groups with a higher level of group leverage carry more debt (LEV). Furthermore the relative amount of bank borrowing (BANK) by these subsidiaries is significantly higher, while the concentration of intra-group debt (INT) is far lower. Differences are significant for both means and medians. Together with Panel A these findings suggest that groups with low debt levels prefer and/or have the capacity to finance their subsidiaries through internal debt. As groups' leverage levels mount, subsidiaries increasingly take on bank debt, while the relative importance of internal financing dwindles. This indicates, consistent with hypothesis $\mathrm{H} 2$, 
that the debt source choice of subsidiaries is not simply a matter of handing group level borrowing down from the central financing office, because then one would expect a positive relationship between group leverage and internal debt use by subsidiaries. Although the more important concentration of bank debt at group level suggests that handing down occurs, consistent with our argument in Section 2, Panel B shows that as group leverage rises, groups increasingly raise bank debt at the subsidiary level, to the detriment of the relative importance of internal debt. However, the preceding univariate approach can only be suggestive, as group leverage is likely also a function of the other group characteristics included in the analysis. Below these issues are investigated in more detail.

\section{Tests and results}

In this Section we first study the determinants of bank debt concentration (Section 5.1) for group firms and stand-alone companies (as a benchmark). Next we evaluate the determinants of the relative use of internal debt by affiliates (Section 5.2). In view of the fact that a non-negligible part of the dependent variables' observations are zero (see univariate statistics in the previous Section), we run Tobit regressions. Tables 4 and 5 present the results. Next, a two equation regression system (2SLS) is set up to investigate the nature of the trade-off (or pecking-order) between both variables for group firms (Section 5.3). Results are given in Table 6. All models control for industry and time effects using dummy variables. 22 The reported standard errors are Huber-White robust.

\subsection{Determinants of bank debt concentration}

Model A from Table 4 serves as a benchmark and shows the results of a model that explains bank debt concentration in stand-alone firms. It includes the firm level variables discussed in Section 3. Note that the inclusion of the level of leverage (LEV) in the model could result in endogeneity problems, as the other independent variables have often been shown to be 
determinants of leverage. ${ }^{23}$ Following Johnson (1997), we regress leverage on all other firm level variables, both in the sample of stand-alone firms and in the sample of subsidiaries. ${ }^{24}$ We then use the residuals of these auxiliary regressions as instrumental variables for leverage. A similar approach is applied to group leverage (GLEV) or group reserves (GRES) in models that include group level variables.

Table 4 about here

$* * * * * * * * * * * * * * * * * * * * * * * *$

For stand-alone firms, five out of six company level characteristics are significant in explaining the relative use of bank debt. First, firms with weak profitability (ROA) use more of it. This is consistent with the hypothesis that shortages in cash generation are filled with extra bank debt. Within our sample this finding is not surprising as it contains mature standalone firms that, given their age, have been able to build a reputation, and hence should be able to increase bank borrowing even in bad times. Furthermore these private companies have no access to public markets and hence have little or no alternative solutions available. Preceding interpretation is also confirmed by the negative sign of age (AGE): older firms have more access to internally generated funds and thus have less need for bank debt. Next, tangibility (TANG), size (SIZE) and overall leverage (LEV) all have a positive sign, as predicted. The coefficient of growth (GROWTH) is negative but insignificant, probably again due to the fact that, although growth entails extra asymmetric information, the sample consists of mature firms which face fewer limitations on the use of bank debt. Overall, the preceding findings indicate that mature private stand-alone firms that can limit the costs of moral hazard and asset substitution and/or are short of cash, use more bank debt. 
Turning to models B and C, the models' fit (adjusted $\mathrm{R}^{2}$ ) shows that it is more difficult to explain the bank debt concentration for group subsidiaries than for stand-alone firms. However, adding group level variables improves $\mathrm{R}^{2}$ from $19.22 \%$ for model $\mathrm{B}$ to $24.52 \%$ for model C. For the subsidiary level variables, findings are in many respects similar to those of the stand-alone sample. Except for growth - which remains insignificant - all coefficients have the same sign. However, after controlling for group characteristics in model C, profitability (ROA) and age (AGE) lose their significance. This could indicate that in group firms, contrary to stand-alones, extra financing needs are not necessarily filled by bank debt. Concerning the group level variables, group size (GSIZE) and group age (GAGE) are significantly negative, while group profitability (GROA) is negative but not significant. This is consistent with the view that as group size, age and profitability increase the resources available in the internal capital market, less bank debt is used by subsidiaries (supportive of hypothesis H1). Furthermore, leverage at the group level (GLEV) is significantly positive. In line with the univariate findings and hypothesis $\mathrm{H} 2$, this suggests that rising group leverage stimulates subsidiaries to acquire bank financing. Consistent with hypothesis H3, it also indicates that, especially if the group has a heavy overall debt burden, large group member firms with important tangible assets borrow directly from a bank. As a robustness check and also to gain more insights, we replace group leverage by group reserves (GRES) in model D. Group reserves has a significantly negative impact on bank borrowing by subsidiaries (the other variables remain unchanged). This is not surprising as GLEV and GRES are strongly negatively correlated ( $\rho$ of -0.61 ). Consistent with our analysis in Section 2 and 3, this indicates that groups tend to fill shortages of internally generated resources with debt so that the resources available in the internal capital market need not increase with group leverage. Rather, our findings suggest that as this shortage of resources increases, groups decrease moral hazard costs by offering external lenders priority rights on the assets of their subsidiaries by raising external debt through these firms. Not surprisingly, because of this 
optimization process, the firm characteristics that shape bank debt concentration in group companies show many similarities with those that shape bank borrowing in stand-alone firms.

Next, to control for any other group-specific characteristics which are not captured by the group level variables in models $C$ and $D$ we add group-specific dummies to models $C^{\prime}$ and $\mathrm{D}^{\prime}$. Group age (GAGE) is excluded from these models, as it is no longer useful in combination with group-specific fixed effects. Table 4 shows that including group-specific dummies has no effect on our main results: the same variables remain significant, with coefficients which are in line with those of models C and D. However, the models' fit has substantially increased: the adjusted $\mathrm{R}^{2}$ rises to 0.4061 for model $\mathrm{C}^{\prime}$ (compared to 0.2452 for model C) and 0.3928 for model D' (compared to 0.2276 for model D).

Finally, model E in Table 4 is estimated on the full sample (i.e. stand-alone plus group sample) and includes all company level characteristics and a dummy variable (GROUP) which has a value of 1 if a firm is part of the group sample. Note that as compared to models A and $C$, its adjusted $\mathrm{R}^{2}$ is lower, although the difference with model $\mathrm{C}$ is only marginal. The significantly negative sign of the group dummy (GROUP $=1$ if group member) confirms the univariate finding that stand-alone companies use more bank debt than group firms, all other things equal.

\subsection{Determinants of internal debt concentration}

Column $\mathrm{F}$ in Table 5 shows the results of estimating the relative use of internal debt by group subsidiaries if only firm level variables are used. Column $G$ contains the findings when group level information is included as well. Comparison of the two models shows that by adding the group level information, the adjusted $\mathrm{R}^{2}$ almost doubles from $13.08 \%$ to 
$21.19 \%$, a much larger increase than for the estimation of bank debt concentration in Table 4.25 This seems to indicate that group level variables are relatively more important in explaining the use of internal debt. In line with hypothesis H3, we find a significant negative sign for subsidiary profitability (ROA) and age (AGE). Referring back to the findings of Table 4 where ROA was not significant in model C, this result may indicate that while standalones use bank debt to fill cash needs, in subsidiaries this role is taken over by internal debt. This is consistent with the use of the internal capital market as a flexible instrument to save on financing costs: intra-group debt comes before bank debt in the pecking order of financing sources (H1). Tangibility (TANG) is not significantly related to the concentration of internal debt. Size (SIZE) has a positive sign, but is no longer significant after controlling for group characteristics. As predicted, growth (GROWTH) has a positive sign, but it is not significant. Finally, in line with hypothesis H3, the overall leverage of the subsidiary (LEV) is significantly positively related to the relative use of internal debt.

Table 5 about here

$* * * * * * * * * * * * * * * * * * * * * * * *$

The findings for the group level variables in model $G$ are, just as in the case of bank debt, fully in line with expectations. As the resources available in the internal capital market rise with increasing group size (GSIZE) and age (GAGE), more internal debt is being used. Important group level leverage (GLEV) reduces intra-group debt concentration at subsidiary level. Analogous to model D in Table 4, model H replaces GLEV by group reserves (GRES). This variable is significant with a positive sign: the more internally generated funds are available, the higher the relative use of intra-group debt, ceteris paribus. Consistent with the findings for bank borrowing by subsidiaries and hypothesis $\mathrm{H} 2$, this points to a process where, as group leverage increases, shortages of internally generated resources tend to be 
filled by additional external debt taken up by subsidiaries, thereby decreasing the relative importance of internal debt in the financing of the latter firms.

In contrast with the case of bank debt, including group-specific dummies (models G' and $\mathrm{H}^{\prime}$ ) does affect some of the results. Most notably, after controlling for group-specific characteristics, both company level sales growth (GROWTH) and group level profitability (GROA) become significant, with positive signs: ceteris paribus, subsidiaries with stronger sales growth (i.e. those subsidiaries which may benefit the most from the flexibility of internal debt) and subsidiaries of more profitable groups (one of the proxies for the availability of funds in the internal capital market) use more internal debt.

As a robustness check, all models in Tables 4 and 5 without group-specific dummies were also estimated using panel data regressions with fixed firm effects. Our main findings (except for the age and group age variables which are no longer meaningful) remain unchanged. As a further robustness check we have also estimated auxiliary regressions to instrument ROA, GROWTH and GROA. Again results are not affected. Finally, correlograms (3 leads and lags; not reported) show that none of the explanatory variables are significantly correlated to the models' error terms.

Overall, the Tobit regressions for internal debt indicate that this form of financing is mainly driven by the resources available in the internal capital market. However, subsidiary level characteristics also play a significant role when the flexibility of internal debt becomes important. As both the bank debt and intra-group debt concentration have drivers in common, the question of the interaction of both forms of financing remains. Section 5.3 looks into this issue. 


\subsection{Simultaneous estimation of bank debt and internal debt concentration}

We test for the nature of the relationship between the relative importance of bank debt (BANK) and internal debt (INT) through a 2SLS system in which both variables are estimated simultaneously. This approach also addresses potential endogeneity problems which may influence the findings from the previous regressions. We report two 2SLS systems of equations in Table 6. The first (System I) is based on the models without groupspecific dummies (model $\mathrm{C}$ in Table 4 for bank debt and model G in Table 5 for internal debt). For reasons of parsimony, given their poor performance in those models, we exclude company growth opportunities (GROWTH) and group level performance (GROA) from the system of equations. Furthermore, to get consistent estimates, not all explanatory variables should be included in both equations: we delete group age (GAGE) from the BANK equation and tangibility (TANG) from the INT equation. ${ }^{26}$

(1)

Table 6 about here

$* * * * * * * * * * * * * * * * * * * * * * * *$

Comparison of the INT column of Table 6 with model G in Table 5 shows that the equation explaining the use of internal debt is not affected by taking potential simultaneity into account. Neither the sign nor the significance of any of the variables is affected. Also the impact on the size of the coefficients and adjusted $R^{2}$ is small. However, the same does not hold true for the equation explaining bank debt. In fact, Table 6 shows foremost that internal debt has a significant negative effect on bank debt, while the latter does not significantly explain the use of internal debt. This confirms that groups use a pecking order in favour of intra-group debt for financing their subsidiaries (hypothesis H1). Furthermore, by adding internal debt (INT) to the bank debt model, the significance of the group level variables from the separate Tobit estimation (model B' of Table 4) disappears. Hence the INT-variable 
subsumes all relevant group information for explaining the concentration of bank debt. Interestingly, the variables at the level of the individual subsidiary are not much affected compared to model C in Table 4, except for profitability (ROA) which becomes significant. A likely reason is that, as shown by the equation explaining internal debt, weakly performing group firms receive more internal debt. However, in practice this type of debt usually is subordinated to bank financing. Consequently, by adding subordinated internal debt - from the perspective of the bank almost as good as adding equity - the group opens up additional opportunities for bank borrowing to help fill cash needs caused by a subsidiary's weak profitability. This simultaneity is not captured by the separate Tobit models, and hence could have biased results in Table 4. Hence, just as stand-alones, group subsidiaries do sometimes also resort to bank debt to fill cash flow shortages. However, groups have the opportunity to use internal debt as an instrument to reduce credit rationing and dissipative costs of bank borrowing by a group firm. This is in line with the predictions of Ghatak and Kali (2001) and the results of e.g. Schiantarelli and Sembenelli (2000). Finally it is interesting to note that the results for the BANK-equation in Table 6 are very similar to those for the stand-alone sample of model A in Table 4. In fact, all variables have the same sign, and there is also a strong correspondence in terms of significance of variables. The only difference concerns the significance of age (AGE). In fact - and not surprisingly - the data support the notion that the role of the availability of internally generated funds, captured by the significant AGEvariable for the stand-alone firms, is taken over by internal debt (INT) for group subsidiaries.

The second system of equations (System II) includes group-specific dummies (cf. model $C^{\prime}$ in Table 4 and model $G^{\prime}$ in Table 5). We again delete group age (GAGE) from the BANK equation and tangibility (TANG) from the INT equation to get consistent estimates. Analogous to the results for System I, the same variables remain important in determining a subsidiary's internal debt concentration (company level profitability, age and sales growth 
and group level size, profitability and leverage). Contrary to System I, group level leverage (GLEV) retains its significance in the BANK equation (subsidiaries of more highly levered groups use more bank debt). More importantly, however, the pecking order hypothesis $(\mathrm{H} 1)$ is confirmed once more: the endogenous INT variable is highly significant in the BANK equation, but the endogenous BANK variable is not significant in the internal debt equation.

\section{Robustness issues}

This section summarizes findings of a number of additional robustness checks and extensions to the analysis.

\subsection{Alternative definitions of internal debt}

We consider two alternative internal debt definitions. As subsidiaries can use the internal capital markets both to lend and borrow, it could lead to potential interpretation problems if the companies in our sample are not the actual beneficiaries of the internal debt, but pass the intra-group resources through to another subsidiary. To address this issue we compute an extra variable expressing the net group financing received as a fraction of total debt (NETGROUP, i.e. (internal debt - financing provided to other group members)/total liabilities)). We also compute the fraction of financing given to other group members to total debt (TOGROUP). If the group companies in our sample systematically pass through the internal debt they receive to other companies, the correlation coefficient between INT and TOGROUP should be highly positive. However, this is not the case: $\rho$ is only 0.163 . On the other hand, the correlation between INT and NETGROUP is very strong (0.836). This indicates that passing through internal debt may occur, but is unlikely to substantially affect our findings. 


\subsection{Taxation}

Taxation rules may add to the attractiveness of internal debt (see Verschueren and Deloof, 2006), even though multinational taxation arbitrage as described by Desai et al. (2004) is not relevant for our sample. The tax-deductibility of interest payments may help in reducing group wide taxation if loss generating affiliates (which do not pay taxes on their extra interest income) grant internal loans to profitable member companies (which can tax deduct paid interests). If this type of taxation game is important, we should observe that affiliates pass through intra-group resources to other subsidiaries to a significant extent. However, the analysis in Section 6.1 shows that such pass-through activity is very limited. In addition, we do not find that subsidiaries with higher return on assets use more internal debt. On the contrary, the ROA proxy is negatively related to internal debt concentration in all models in Tables 5 and 6 . In fact, as alternative and very flexible tools to shift costs within the group are available (e.g. mutual cost sharing agreements between affiliates), it may not be surprising that groups make little use of internal debt to shift taxable profit from one subsidiary to another.

Another tax related argument concerns the fact that in Belgium dividends are taxed at $25 \%$ and intra-corporation dividends are not completely tax exempt (most intra-group dividends are $95 \%$ tax exempt under the so-called DBI double taxation regime). This implies that business groups may have an incentive to redistribute internally generated cash surpluses in the form of interest, rather than dividends. However as the tax treatment of internal debt is the same as that of external debt, such a tax advantage would enhance the overall use of financial debt, rather than determine the choice between bank and internal debt. 


\subsection{Subsidiaries with ultra high leverage}

It could be argued that some group affiliates systematically use large amounts of internal debt to pursue an ultra high leverage strategy, for instance to minimize taxes. However, because of our broad definition of leverage (see footnote 20) only a very small number of companies exceed the $100 \%$ leverage boundary. Specifically, dropping the $100 \%$ leverage cut-off would add no more than 12 companies to the group sample and would result in an increase of 42 testable firm years $(+2.3 \%)$. In the stand-alone sample - before matching for size and industry - there would be 10 extra companies (33 firm years). Robustness checks show that including these companies does not affect results. The ultra high leverage group subsidiaries have a very high internal debt concentration (median of 0.5364 ), but also use relatively much bank debt (median of 0.2452 ). The ultra high leverage stand-alone companies have a substantially lower bank debt concentration (median of 0.1393), while their profitability, sales growth or tangibility are not significantly different from that of the ultra high leverage subsidiaries. This may indicate that the ultra high leverage stand-alone companies are credit rationed by banks to a larger extent than group subsidiaries with comparable characteristics.

\subsection{Ownership and diversification}

As a further robustness check, we control for ownership concentration and group diversification. To that end we construct two new dummy variables. The first (WO) has a value of 1 if the subsidiary is wholly owned (>99\% of shares) by the group. Claessens et al. (2006) and Bianco and Nicodano (2006) argue that the nature of the agency problems and the potential benefits of belonging to a group may depend on the degree of ownership or the cash flow rights held by the parent. However, it should be noted that ownership concentration in our non-stock exchange quoted business groups is very high, as minority shareholders are likely to face more problems (e.g. no liquidity, low transparency) than 
minority shareholders of quoted companies. In practice, $75.5 \%$ of all subsidiaries in our sample are wholly owned (WO is 1 in $78.7 \%$ of all firm years). When we look at univariate statistics (not reported), we do find differences in bank debt and internal debt use between wholly owned and non-wholly owned companies: wholly owned subsidiaries use significantly more internal debt and less bank debt.

The second additional dummy variable (DIVERS) proxies for group diversification and has a value of 1 if the consolidated group reports more than 3 different NACE activity codes. The degree of group diversification may matter as subsidiaries in a concentrated group may have more opportunities for using the internal capital markets, for instance through intra-group trade. Unfortunately, we cannot construct a more detailed concentration measure (e.g. a Herfindahl index) because our group sales data is not split up by business line or activity code. It turns out that our non-financial private business groups are quite concentrated (DIVERS has a value of 1 in only 11.3\% of firm years). Furthermore, there is only a significant difference (at the $10 \%$ level) in mean internal debt use which - consistent with the argument above - is higher for subsidiaries in non-diversified groups.

When we add the WO and DIVERS27 variables to the models in Tables 4, 5 and 6 (results not reported) WO proves to be highly significant in the separate models (cf. Tables 4 and 5), both for BANK (negative sign) and for INT (positive sign). In the systems of equations (cf. Table 6), WO is only significant as a determinant of INT (wholly owned subsidiaries use more internal debt), again suggesting that internal capital market related information is more relevant for explaining internal debt than bank debt. DIVERS is never significant, neither in the separate models, nor in the system of equations. Our models cannot distinguish whether the positive relationship between WO and internal debt use is driven by wholly owned subsidiaries being more actively integrated in the internal capital 
markets, or whether non-wholly owned subsidiaries have a lower demand for internal loans (e.g. to protect their partial independence), as both explanations would lead to the same result. However, the robustness checks do show that controlling for these issues does not affect our main conclusions.

\subsection{Trade credit}

Trade credit is an important source of finance for our sample companies (median of $40.74 \%$ in stand-alone companies and $35.88 \%$ in group firms). We do not explicitly include trade credit in our analysis because the transaction motive for the use of this form of financing is likely to dominate in the large and mature firms in our sample. As an extra robustness check on this assumption we run an OLS regression for the 1-yr change in trade credit concentration (not reported). For both subsets of firms, the profitability proxy (ROA) has a negative sign, but is not significant, while the sales growth proxy (GROWTH) is highly significant with a positive sign. Nevertheless, it is interesting to note that the relative use of trade credit is significantly lower for group member companies as compared to stand-alone companies, both in means $(43.45 \%$ in stand-alone companies and $39.50 \%$ in group companies; t-test score: 4.600$)$ and in medians (40.74\% in stand-alone companies and $35.88 \%$ in group companies; Mann-Whitney test score: 5.210). The difference in use of external trade credit is likely even more important, given the fact that in the stand-alone sample all trade credit is external by definition and part of the trade credit in the group sample may be internal. This could suggest that the (expensive) use of trade credit for financing purposes, which a limited number of the stand-alone companies may have to resort to, can be avoided by affiliates. Unfortunately, the comments to the financial statements do not include a breakup of trade credit into internal and external sources, so this issue cannot be explored further (cf. Desai et al., 2004). ${ }^{28}$ 


\section{Conclusions}

This paper is the first to empirically examine how domestic private business groups determine the debt source concentration of subsidiaries. This is realized by modelling in detail the mix of bank and internal debt in affiliates, using both company level and group level characteristics. Simultaneously, as this study also considers stand-alone firms as a benchmark, it compares the bank debt acquisition process between both types of firm and pinpoints the impact of group membership.

We find that the firm level variables that drive the acquisition process of bank debt are very similar between stand-alones and group member companies. Large firms with many tangible assets use more bank debt, while - a standard result in the literature - a higher level of total leverage is also associated with a larger portion of bank borrowing. However there is one major difference: a pecking order in favour of internal debt negatively impacts on bank debt concentration in group firms, so that the latter make less use of it than comparable stand-alone firms. This pecking order in favour of internal debt can be explained by significant cost savings from the use of the internal capital market. Not surprisingly then, the internal debt concentration of a subsidiary is mainly driven by the characteristics of this market. The more resources available, the more internal debt is used, while bank debt financing at subsidiary level decreases. The use of internal debt is highest in those subsidiaries which could be expected to have limited access to external financing (i.e. smaller and less profitable subsidiaries). However, because important overall group level leverage is associated with a shortfall in internally generated resources, extra group leverage reduces internal debt concentration and stimulates bank borrowing by large subsidiaries with many tangible assets. This finding indicates that, in such a case, moral hazard problems are 
minimised as direct contracting with the subsidiary allows the bank to acquire seniority claims over the subsidiary's assets.

Our results show that optimization of financing costs through internal capital markets is not limited to multinational corporations as described by Desai et al. (2004), but that optimization also takes place across subsidiaries operating within the same legal and taxation framework. Although capital structure optimization may give multinational corporations an advantage over local competitors, our research indicates that this advantage is not equally important across different types of domestic companies. Domestic business groups also have optimization advantages over stand-alone competitors. In this respect, it would be interesting to study whether multinational corporations not only optimize across countries, but also across affiliates within the same country, and which type of optimization offers the best scope for cost savings. Our analysis also suggests that an important implicit cost of increasing group wide leverage is that, in order to avoid mounting moral hazard problems, groups have to accept that bank borrowing is immediately tied to collateral assets in subsidiaries, thereby largely bypassing the cost savings from the internal capital market. From the perspective of credit risk assessment models, contrary to what is presently the case in most models, our findings stress the need to simultaneously use group level and subsidiary level information.

As a caveat, it is important to note that our analysis does not capture the entire structure of a typical business group, as it is limited to large operating subsidiaries and the top-level parent company. Most business groups also have a number of smaller operating subsidiaries. For these companies, which only file abbreviated financial statements, it is impossible to ascertain the amount of internal debt used. However, their lack of size makes it unlikely that they play an important role in the overall financing strategy of the group. Many 
business groups also have non-operating or financial subsidiaries which can be used for special purposes (control, taxation, management services, etc.). Unfortunately, these companies cannot be analyzed in the same way as operating subsidiaries as they often have sales which are close to zero and very few or no tangible assets, which renders many of the standard control variables useless. Moreover, it is impossible to compare these nonoperating subsidiaries to stand-alone counterparts as they are unique to the group phenomenon.

A final point of notice is that our results on the process of acquiring bank and internal debt may be different within groups with stock market quoted components, as this may affect some of the trade-offs that shape the choice between the use of bank or internal debt by subsidiaries. Further research may shed more light on these issues. 
$132.4 \%$ of the 100,000 largest companies in terms of total revenue based on Bureau Van Dijk EP's AMADEUS database (version September 2006), using a full control $(>50.01 \%)$ criterion.

2 Belgium is a typical civil law country where external capital markets are relatively underdeveloped compared to the Anglo Saxon world (cf. La Porta et al., 1998), and where most firms finance through internal resources, internal capital markets and private debt (mostly bank debt). Equity market capitalization at the end of September 2002 was $49.1 \%$ of GDP for Belgium, compared to $98.5 \%$ for the USA and a European Union average of $65.7 \%$. The value of outstanding corporate debt securities equaled $9.8 \%$ of GDP (US: $22.9 \%$, EU: $9.5 \%$ ).

${ }^{3}$ The evidence on the use of different types of debt in European companies typically focuses on the use of bank debt versus trade credit (e.g. Mateut and Mizen, 2002; Nilsen, 2002; Lopéz Itturiaga, 2005; de Andrés Alonso et al., 2005; Huyghebaert and Van de Gucht, 2007). This literature shows that the choice between trade credit financing and bank debt is mainly an issue for small and young firms. Our sample contains mature and larger sized companies for which the financing motive of trade credit should be of less concern (see Section 6.5).

${ }^{4}$ It should be noted that, in theory, private group subsidiaries could also fill extra financing needs by internal equity. In practice however this does not seem to occur. Because internal debt is much more flexible and cheaper (both in terms of fees and taxation treatment) than equity, less than $1 \%$ of the subsidiaries in our sample have issued stock during our six year sample period.

${ }^{5}$ In our Continental European setting, non-quoted is not synonymous with small. Many of the business groups in our sample are among the largest competitors in their industry on a national or European level (average consolidated sales of 250.3 million euros). In fact, even virtually all of the individual group affiliates we consider would meet the size requirements for stock exchange quotation in Europe (e.g. Euronext only requires minimal free float of 2.5 million euros, Deutsche Börse of 1.5 million euros).

${ }^{6}$ E.g. groups may use a financial subsidiary instead of the top level firm to centralize financial operations. In this respect, Deloof (2001) shows that cost saving may occur because individual group member companies have lower needs for liquid reserves, as intra-group claims can easily be adjusted.

${ }^{7}$ In practice the benefits of this policy may be limited though, as the failure of a large subsidiary is likely to have a strong negative impact on group reputation. In fact, Dewaelheyns and Van Hulle (2006) find empirical evidence indicating that Belgian business groups continue to support their troubled operating subsidiaries for as long as they can manage.

8 Note that in Belgium, as in many other countries, if a group wants to pledge a member company's assets as collateral for an external loan, this loan has to be contracted by that specific member company because of its separate legal identity.

${ }^{9}$ It should be noted that providing more internal financing to these types of subsidiary may also be driven by a less positive explanation which is often referred to as 'socialism within the group', i.e. allocating resources to inefficient activities (Scharfstein and Stein, 2000; Shin and Stulz, 1998).

${ }^{10}$ Some of the arguments in this literature may depend upon the type of firm under consideration. Specifically, for studies covering only public companies, the relationships between firm specific variables and bank debt may be the opposite to those in private firms because the former have access to both public equity and public debt (Johnson 1997, 1998; Hooks, 2003; Bevan and Danbold, 2002, among others). Other studies consider very small firms and/or start ups (e.g. Petersen and Rajan, 1994; Huyghebaert and Van de Gucht, 2007). As to be expected, the evidence in these cases may show class specific properties of the debt acquisition process.

${ }^{11}$ Note that the situation may be different for quoted companies: tangibility may more strongly promote the use of public debt, leading to a negative relation between bank debt use and tangibility (e.g. Johnson, 1997 and Denis and Mihov, 2003).

12 Just as in the case of tangibility, the relationship between size and the use of bank debt may be different for public firms. Johnson (1997) and Hooks (2003) among others document a negative relation between bank debt and size but a positive relation between public debt and size.

${ }^{13}$ McConnell and Servaes (1995) document that even in public firms, debt servicing hinders growth firms. In line with this perspective, Bevan and Danbolt (2002) report a negative relationship between growth opportunities and the relative importance of bank debt for their sample of public firms.

${ }_{14}$ Under Belgian Accounting Law, companies are required to file complete (unconsolidated) accounts if they meet at least two of the following criteria: total assets exceed 3.125 million euro, operating revenue exceeds 6.25 million euro, more than 50 full time equivalent employees. Companies with more than 100 full time equivalent employees always have to file complete accounts. All other firms may file abbreviated accounts.

15 The Law defines control as owning more than $50 \%$ of the shares or the votes, or having common controlling shareholders who can appoint the majority of the board or can make strategic decisions. This control can also be the result of company bylaws, contracts or the existence of a consortium. Information on affiliated companies is reported in the comments to the financial statements.

16 Although limiting the data set to groups with consolidated accounts introduces a potential size bias, it ensures that the information at the group level captures economic reality as accurately as possible. Specifically, companies are exempted from filing consolidated accounts if they do not surpass more than one of the following criteria: revenues of 20 million EUR, total assets of 10 million EUR, or 250 employees (on average, in full time 
equivalents). As an alternative to using consolidated accounts Manos et al. (2001) or Chang and Hong (2000) compute group level variables as the value weighted average of the individual member firms' variables. Although this approach circumvents the need for consolidated statements, it is likely to lead to information quality problems in our non-quoted sample.

${ }^{17}$ See Section 6.3 for a robustness check.

18 Using the full stand-alone sample would lead to important differences in size and industry distribution across samples. The total assets of the median group sample company are more than twice as large as those of the median firm in the full stand-alone sample. The latter sample contains substantially more wholesale and retail companies $(46.4 \%$ vs. $24.2 \%$ in the group sample), while the group sample has more manufacturers $(37.3 \%$ vs. $27.5 \%$ in the stand-alone sample). Industry matching is based on a 2-digit NACE classification code. As a robustness check, all tests were rerun on the full stand-alone sample. Results are analogous and available upon request.

19 Because we only select non-financial subsidiaries that file complete accounts, the average number of subsidiaries per group only amounts to 2.18 firms. Within the sample, the maximal number of subsidiaries from the same group is 13, implying that no business group has a dominant presence.

${ }^{20}$ Note that we use an overall leverage proxy (LT + ST liabilities over total assets) - which is close to the one used in Desai et al. (2004) - while the vast majority of Anglo-Saxon studies use long-term debt as a measure of leverage. However, Titman and Wessels (1988) point out that in countries where short-term liabilities are important financing sources, measures of leverage should include these as well. The importance of short-term debt in Belgium has been confirmed by e.g. Deloof and Jegers (1999). Some authors also argue that one should empirically distinguish between short- and long-term debt (see e.g. Antoniou et al., 2006 for a study of debt maturity determinants). However, as pointed out by Johnson (1997), due to roll-over structures, debt covenants, etc., it is often impossible to distinguish short-term from long-term debt in a meaningful way.

21 This implies that potential endogeneity problems between subsidiary and group level variables are limited. The correlation matrix of key variables (not reported but available upon request) corroborates this as it shows relatively low levels of correlation between company level variables and their group level counterparts (correlation coefficients range between -0.00 for age (AGE) and group age (GAGE) and 0.41 for profitability (ROA) and group profitability (GROA)).

22 Industry effects are captured by 20 dummy variables based on 2-digit NACE codes (coefficients not reported). All 2-digit NACE codes with insufficient observations (less than 20) are included in the base category.

23 Other multicollinearity problems should be relatively unimportant, as, except for GLEV and GRES, the correlation between company level variables is limited (correlation matrix available upon request).

24 Alternatively, a separate model for leverage could be specified and simultaneously estimated with the debt source models. However, if the system of equations is recursive (as is the case; estimations not reported), simultaneous estimation becomes unnecessary and the auxiliary regression approach leads to correct results (Hooks, 2003).

${ }^{25}$ Note that except for size (SIZE) the coefficients of the firm level variables in models $F$ and $G$ are very similar. The change for size (SIZE), and especially its loss of significance in model G, may be explained by the fact that larger subsidiaries are more likely to be part of larger groups. As group size has a significant impact on the use of internal debt, contrary to model G where group size has been included, in model F subsidiary size is likely to partially pick up this group size effect.

${ }^{26}$ GLEV is preferred over GRES, as Tables 4 and 5 show the former leads to a better fit. As a robustness check we re-estimated the systems of Table 6 with GLEV replaced by GRES. Results are consistent with those reported.

${ }^{27}$ DIVERS is only included in the models without group-specific dummies as there is very little variation in group diversification through time.

${ }^{28}$ Debt sources other than bank debt, internal debt and trade credit are not important in our sample. Our sample firms cannot issue public bonds. They may issue private bonds or use leasing. Although a few companies actively use these debt sources, they are not important on average (median is zero for both sources). The differences in means for both bonds and leasing are statistically significant across samples (higher for group members), but do not appear to be economically meaningful (bonds/total liabilities: mean of 0.024 for stand-alones, 0.044 for group members; lease debt/total liabilities: mean of 0.011 for stand-alones, 0.015 for group members). The final debt source is taxes, wages and social security liabilities, which has a mean of around 0.10 and a median of about 0.07 for both samples. Typically, this debt source's importance is relatively constant through time and is unlikely to be used for financing purposes. 


\section{References}

Antoniou, A., Guney, Y. and Paudyal, K., 'The determinants of debt maturity structure: evidence from France, Germany and the UK', European Financial Management, Vol. 12, 2006, pp.161-94.

Bevan, A.A. and Danbolt, J., 'Capital structure and its determinants in the United Kingdom: a decompositional analysis', Applied Financial Economics, Vol. 12, 2002, pp. 159-70.

Bianco, M. and Nicodano, G., 'Pyramidal groups and debt', European Economic Review, Vol. 50, 2006, pp. 937-61.

Bond, P., 'Bank and nonbank financial intermediation', Journal of Finance, Vol. 59, 2004, pp. 2489-529.

Boot, A., Thakor, A. and Udell, G., 'Secured lending and default risk: equilibrium analysis and policy implications and empirical results', Economic Journal, Vol. 101, 1991, pp. 45872.

Buysschaert, A., Deloof, M. and Jegers, M., 'Equity sales in Belgian corporate groups: expropriation of minority shareholders? A Clinical Study', Journal of Corporate Finance, Vol. 10, 2004, pp. 81-103.

Carey, M., Post, M. and Sharpe, S.A., 'Does corporate lending by banks and financing companies differ? Evidence on specialization in private debt contracting', Journal of Finance, Vol. 22, 1998, pp. 613-73.

Chang, S.J. and Hong, J., 'Economic performance of group-affiliated companies in Korea: intragroup resource sharing and internal business transactions', Academy of Management Journal, Vol. 43, 2000, pp. 429-48.

Claessens, S., Fan, J.P.H. and Lang, L.H.P., 'The benefits and costs of group affiliation: evidence from East-Asia', Emerging Markets Review, Vol. 7, 2006, pp. 1-26.

De Andrés Alonso, P., Lopéz Itturiaga, F.J., Rodríguez Sanz, J.A. and Vallelado González, E., 'Determinants of bank debt in a Continental financial system: evidence from Spanish companies', Financial Review, Vol. 40, 2005, pp. 305-33.

Deloof, M., 'Belgian intragroup relations and the determinants of corporate liquid reserves', European Financial Management, Vol. 7, 2001, pp. 375-92.

Deloof, M. and Jegers, M., 'Trade credit, corporate groups, and the financing of Belgian firms', Journal of Business Finance and Accounting, Vol. 26, 1999, pp. 945-66.

Denis, D.J. and Mihov, V.T., 'The choice among bank debt, non-bank private debt and public debt: evidence from new corporate borrowings', Journal of Financial Economics, Vol. 70, 2003, pp. 3-28.

Desai, M.A., Foley, C.F. and Hines, J.R., 'A multinational perspective on capital structure choice and internal capital markets', Journal of Finance, Vol. 59, 2004, pp. 2451-87.

Detragiache, E., 'Public versus private borrowing: a theory with implications for bankruptcy reform', Journal of Financial Intermediation, Vol. 3, 1994, pp. 327-54.

Dewaelheyns, N. and Van Hulle, C., 'Corporate failure prediction modelling: distorted by business groups' internal capital markets?' Journal of Business Finance and Accounting, Vol. 33, 2006, pp. 909-31.

Diamond, D., 'Financial intermediation and delegated monitoring', Review of Economic Studies, Vol. 51, 1984, pp. 393-414.

Diamond, D., 'Monitoring and reputation: the choice between bank loans and directly placed debt', Journal of Political Economy, Vol. 99, 1991, pp. 689-721.

Easterwood, J.C. and Kadapakkam, P.R., 'The role of private and public debt in corporate capital structures', Financial Management, Vol. 20, 1991, pp. 49-57.

Fama, E.F., 'What's different about banks?', Journal of Monetary Economics, Vol. 15, 1985, pp. 29-39. 
Gadhoum, Y., Lang, L.H.P. and Young, L., 'Who controls US?', European Financial Management, Vol. 11, 2005, pp. 339-63.

Gaud, P., Jani, E., Hoesli, M. and Bender, A., 'The capital structure of Swiss companies: an empirical analysis using dynamic panel data', European Financial Management, Vol. 11, 2005, pp.51-69.

Gertner, R.H., Scharfstein, D.S. and Stein, J.C., 'Internal versus external capital markets', Quarterly Journal of Economics, Vol. 109, 1994, pp. 1211-30.

Ghatak, M. and Kali, R., 'Financially Interlinked Business Groups', Journal of Economics $\mathcal{E}$ Management Strategy, Vol. 10, 2001, pp. 591-619.

Gul, F.A., 'Growth opportunities, capital structure and dividend policies in Japan', Journal of Corporate Finance, Vol. 5, 1999, pp. 141-68.

Hall, G., Hutchinson, P. and Michaelas, N., 'Industry effects on the determinants of unquoted SME's capital structure', International Journal of the Economics of Business, Vol. 7, 2000, pp. 297-312.

Hooks, L.M., 'The impact of firm size on bank debt use', Review of Financial Economics, Vol. 12, 2003, pp. 173-89.

Hoshi, T., Kashyap, A. and Scharfstein, D., 'The role of banks in reducing the costs of financial distress in Japan', Journal of Financial Economics, Vol. 27, 1990, pp. 67-88.

Hoshi, T., Kashyap, A. and Scharfstein, D., 'The choice between public and private debt: an analysis of post-regulation corporate financing in Japan' Working Paper (National Bureau of Economic Research, 1993).

Houston, J. and James, C., 'Bank information monopolies and the mix of private and public debt claims', Journal of Finance, Vol. 51, 1996, pp. 1863-89.

Huyghebaert, N. and Van de Gucht, L., 'The determinants of financial structure: new insights from business start-ups', European Financial Management, Vol. 13, 2007, pp. 10133.

Johnson, S.A., 'An empirical analysis of the determinants of corporate debt ownership structure', Journal of Financial and Quantitative Analysis, Vol. 32, 1997, pp. 47-69.

Johnson, S.A., 'The effect of bank debt on optimal capital structure', Financial Management, Vol. 27, 1998, pp. 47-56.

La Porta, R., Lopez de Silanes, F., Shleifer, A. and Vishny, R., 'Law and finance', Journal of Political Economy, Vol. 106, 1998, pp. 1113-55.

Lamont, O., 'Cash flow and investment: evidence from internal capital markets', Journal of Finance, Vol. 52, 1997, pp. 83-109.

Leeth, J. and Scott, J., 'The incidence of secured debt: evidence from the small business community', Journal of Financial and Quantitative Analysis, Vol. 24, 1989, pp. 379-94.

Lopéz Iturriaga, F.J., 'Debt ownership structure and legal system: an international analysis', Applied Economics, Vol. 37, 2005, pp. 355-65.

Manos, R., Murinde, V. and Green, C.J., 'Business groups and capital structure: evidence on Indian firms', Working Paper (University of Manchester, 2001).

Marsh, P., 'The choice between equity and debt: an empirical study', Journal of Finance, Vol. 37, 1982, pp. 121-44.

Mateut, S. and Mizen, P., 'Trade credit and bank lending: an investigation into the determinants of UK manufacturing firms' access to trade credit', Working Paper (University of Nottingham, 2002).

McConnell, J.J. and Servaes, H., 'Equity ownership and the two faces of debt', Journal of Financial Economics, Vol. 39, 1995, pp. 131-57.

Myers, S.C., 'Capital structure', Journal of Economic Perspectives, Vol. 15, 2001, pp. 81-102.

Myers, S.C. and Majluf, N.S., 'Corporate financing and investment decisions when firms have information the investors do not have', Journal of Financial Economics, Vol. 13, 1984, pp. 81-102. 
Nilsen, J., 'Trade credit and the bank lending channel', Journal of Money, Credit and Banking, Vol. 34, 2002, pp. 226-53.

Petersen, M.A. and Rajan, R.G., 'The benefits of lending relationships: evidence from small business data', Journal of Finance, Vol. 49, 1994, pp. 3-37.

Petersen, M.A. and Rajan, R.G., 'Trade credit: theories and evidence', Review of Financial Studies, Vol. 10, 1997, pp. 661-91.

Rajan, R.G. and Zingales, L., 'What do we know about capital structure: some evidence from international data', Journal of Finance, Vol. 50, 1995, pp. 1421-60.

Ramakrishnan, R.T.S. and Thakor, A.V., 'Information reliability and a theory of financial intermediation', Review of Economic Studies, Vol. 84, 1984, pp. 415-32.

Scharfstein, D. and Stein, J., 'The dark side of internal capital markets: divisional rent seeking and inefficient investing', Journal of Finance, Vol. 55, 2001, pp.2537-64.

Schiantarelli, F. and Sembenelli, A., 'Form of ownership and financial constraints: panel data evidence from leverage and investment equations', Empirica, Vol. 27, 2000, pp. 175-92.

Shin, H-H. and Stulz, R.M., 'Are internal capital markets efficient?', Quarterly Journal of Economics, Vol. 113, 1998, pp. 531-50.

Shyam-Sunder, L. and Myers, S.C., 'Testing static tradeoff against pecking order models of capital structure', Journal of Financial Economics, Vol. 51, 1999, pp. 219-44.

Smith, J., 'Trade credit and information asymmetry', Journal of Finance, Vol. 42, 1987, pp. 86372.

Stein, J.C., 'Internal capital markets and the competition for corporate resources', Journal of Finance, Vol. 52, 1997, pp. 83-109.

Titman, S. and Wessels, R., 'The determinants of capital structure choice', Journal of Finance, Vol. 43, 1988, pp.1-19.

Verschueren I. and Deloof, M., 'How does intragroup financing affect leverage? Belgian evidence', Journal of Accounting, Auditing and Finance, Vol. 21, 2006, pp. 83-108. 
Table 1

Sample industry composition

This table shows the industry composition of the sample of 553 business group subsidiaries and 553 matched stand-alone companies. Industry classification is based on NACE-BEL codes obtained from the BelFirst financial statement database.

\begin{tabular}{lcc}
\hline \multicolumn{1}{c}{ Industry } & $\begin{array}{c}\text { Number of firms in group } \\
\text { and stand-alone samples }\end{array}$ & $\%$ \\
\hline Food & 78 & 14.1 \\
Manufacturing & 206 & 37.3 \\
Construction & 66 & 11.9 \\
Trade (Wholesale \& Retail) & 134 & 24.2 \\
Transportation & 59 & 10.7 \\
Other & 10 & 1.8 \\
& 553 \\
\hline
\end{tabular}


Table 2

Definition of main variables

This table gives the definitions of the main variables used in the univariate and multivariate tests. The debt source variables and the company level characteristics are computed using data from the financial statements of 553 business group subsidiaries and 553 stand-alone companies. The group level characteristics use consolidated financial statement data of 253 non-financial business groups.

\begin{tabular}{ccc}
\hline Variable & Definition & Proxy \\
Name & & for \\
\hline
\end{tabular}

Debt Source Variables

BANK

(bank debt)/(ST liabilities + LT liabilities )

INT
Bank Debt

Concentration

Internal Debt

Concentration

Company Level Characteristics

ROA

$$
\text { (operating profits }) /(\text { total assets })
$$

Profitability

TANG

$$
(\text { tangible fixed assets }+ \text { inventory }) /(\text { total assets })
$$

Tangibility

SIZE

$$
\text { Ln(total assets) }
$$

Size

AGE

$$
\text { Ln(years since incorporation date) }
$$

Age

GROWTH

$$
\left(\text { sales }_{\mathrm{t}}-\text { sales }_{\mathrm{t}-1}\right) / \text { sales }_{\mathrm{t}-1}
$$

Growth Opportunities

LEV (ST liabilities + LT liabilities $) /($ total assets $)$

Leverage

Group Level Characteristics
GSIZE
Ln(group total assets)
Group Size
GAGE
Ln(years since group incorporation date)
Group Age
GROA (group operating profits)/(group total assets)
Group
Profitability
GLEV (group ST liabilities + group LT liabilities)/(group total assets)
Group Leverage
GRES

$$
\text { (group reserves }+ \text { retained earnings }) /(\text { group total assets })
$$
Group Reserves 
Table 3

Summary statistics and univariate tests

Panel A of this table provides summary statistics and univariate tests for the main company level characteristics, group level characteristics and debt sources based on financial statements of 553 companies in the stand-alone sample, 553 companies in the group sample and 253 consolidated business group financial statements. The left-hand side reports medians for the stand-alone and group samples, minimum/maximum and standard deviations in square brackets and Wilcoxon Mann-Whitney tests for equality of medians across samples (Wilcoxon T-statistics in parentheses); the right-hand side reports means for the stand-alone and group samples, standard deviations in square brackets and t-tests for equality of means across samples (t-statistics in parentheses). GBANK is the bank debt concentration for the consolidated group $=($ group bank debt) $/$ (group ST liabilities + group LT liabilities $)$. The other variables are defined in Table 2. Panel B shows bank and internal debt concentration split up according to whether group leverage is amongst the $50 \%$ highest or lowest of all groups in the sample. ${ }^{* *}$ denotes significance at the $1 \%$ level; ** denotes significance at the $5 \%$ level; * denotes significance at the $10 \%$ level

Panel A - General descriptives and tests

\begin{tabular}{|c|c|c|c|c|c|c|}
\hline \multirow{2}{*}{ Variable } & \multicolumn{3}{|c|}{ Median [Min;Max] } & \multicolumn{3}{|c|}{ Mean [StDev] } \\
\hline & $\begin{array}{c}\text { Stand-Alone } \\
\text { Sample }\end{array}$ & $\begin{array}{l}\text { Group } \\
\text { Sample }\end{array}$ & & $\begin{array}{l}\text { Stand-Alone } \\
\text { Sample }\end{array}$ & $\begin{array}{l}\text { Group } \\
\text { Sample }\end{array}$ & \\
\hline \multicolumn{7}{|c|}{ Company level characteristics } \\
\hline ROA & $\begin{array}{c}0.0442 \\
{[-0.344 ; 0.486]}\end{array}$ & $\begin{array}{c}0.0377 \\
{[-0.361 ; 0.447]}\end{array}$ & $(2.923)^{* * *}$ & $\begin{array}{l}0.0555 \\
{[0.079]}\end{array}$ & $\begin{array}{l}0.0489 \\
{[0.083]}\end{array}$ & $(2.024)^{* *}$ \\
\hline TANG & $\begin{array}{c}0.4370 \\
{[0 ; 0.991]}\end{array}$ & $\begin{array}{c}0.3453 \\
{[0 ; 0.979]}\end{array}$ & $(6.983)^{* * *}$ & $\begin{array}{l}0.4274 \\
{[0.228]}\end{array}$ & $\begin{array}{l}0.3639 \\
{[0.234]}\end{array}$ & $(6.935)^{* * *}$ \\
\hline SIZE & $\begin{array}{c}9.1718 \\
{[7.515 ; 12.008]}\end{array}$ & $\begin{array}{c}9.4848 \\
{[5.389 ; 11.784]}\end{array}$ & $(7.965)^{* * *}$ & $\begin{array}{l}9.2540 \\
{[0.645]}\end{array}$ & $\begin{array}{l}9.5989 \\
{[1.091]}\end{array}$ & $(9.890)^{* * *}$ \\
\hline AGE & $\begin{array}{c}3.0910 \\
{[0.693 ; 4.605]}\end{array}$ & $\begin{array}{c}2.9444 \\
{[0.693 ; 4.615]}\end{array}$ & $(2.163)^{* *}$ & $\begin{array}{l}3.0322 \\
{[0.711]}\end{array}$ & $\begin{array}{l}2.9622 \\
{[0.745]}\end{array}$ & $(2.434)^{* *}$ \\
\hline GROWTH & $\begin{array}{c}0.0469 \\
{[-0.319 ; 0.622]}\end{array}$ & $\begin{array}{c}0.0326 \\
{[-0.264 ; 0.584]}\end{array}$ & $(2.242)^{* *}$ & $\begin{array}{l}0.0645 \\
{[0.178]}\end{array}$ & $\begin{array}{l}0.0541 \\
{[0.178]}\end{array}$ & $(1.469)$ \\
\hline LEV & $\begin{array}{c}0.6634 \\
{[0.109 ; 0.999]}\end{array}$ & $\begin{array}{c}0.6708 \\
{[0.102 ; 0.998]}\end{array}$ & $(1.261)$ & $\begin{array}{l}0.6176 \\
{[0.227]}\end{array}$ & $\begin{array}{l}0.6309 \\
{[0.213]}\end{array}$ & $(1.536)$ \\
\hline \multicolumn{7}{|c|}{ Group level characteristics } \\
\hline GSIZE & 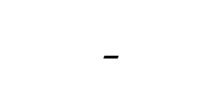 & $\begin{array}{c}11.7266 \\
{[7.367 ; 15.918]}\end{array}$ & - & - & $\begin{array}{l}11.7747 \\
{[1.177]}\end{array}$ & - \\
\hline GAGE & - & $\begin{array}{c}2.9957 \\
{[0.693 ; 4.615]}\end{array}$ & - & - & $\begin{array}{l}3.0472 \\
{[0.977]}\end{array}$ & - \\
\hline GROA & - & $\begin{array}{c}0.0421 \\
{[-0.117 ; 0.368]}\end{array}$ & - & - & $\begin{array}{l}0.0470 \\
{[0.050]}\end{array}$ & - \\
\hline GLEV & - & $\begin{array}{c}0.6370 \\
{[0.101 ; 0.975]}\end{array}$ & - & - & $\begin{array}{l}0.6205 \\
{[0.163]}\end{array}$ & - \\
\hline GRES & - & $\begin{array}{c}0.1432 \\
{[-0.551 ; 0.848]}\end{array}$ & - & - & $\begin{array}{l}0.1445 \\
{[0.158]}\end{array}$ & - \\
\hline \multicolumn{7}{|l|}{ Debt sources } \\
\hline BANK & $\begin{array}{c}0.1961 \\
{[0 ; 0.944]}\end{array}$ & $\begin{array}{c}0.1176 \\
{[0 ; 0.995]}\end{array}$ & $(5.525)^{* * *}$ & $\begin{array}{l}0.2438 \\
{[0.228]}\end{array}$ & $\begin{array}{l}0.2128 \\
{[0.242]}\end{array}$ & $(4.134)^{* * *}$ \\
\hline$\%$ non-zero & $80.6 \%$ & $70.1 \%$ & & $80.6 \%$ & $70.1 \%$ & \\
\hline INT & - & $\begin{array}{c}0.1345 \\
{[0 ; 0.999]}\end{array}$ & - & - & $\begin{array}{l}0.2496 \\
\lceil 0.274]\end{array}$ & - \\
\hline$\%$ non-zero & - & $84.6 \%$ & - & - & $84.6 \%$ & - \\
\hline GBANK & - & $\begin{array}{c}0.3244 \\
\lceil 0 ; 0.864\rceil\end{array}$ & - & - & $\begin{array}{l}0.3349 \\
{[0.198]}\end{array}$ & - \\
\hline$\%$ non-zero & - & $\begin{array}{l}97.0 \% \\
97.2 \%\end{array}$ & - & - & $\begin{array}{l}10.1901 \\
97.2 \%\end{array}$ & - \\
\hline
\end{tabular}


Panel B - Leverage, bank and internal debt concentration \& group leverage

\begin{tabular}{cccc|ccc}
\hline Variable & \multicolumn{3}{c|}{ Median } & \multicolumn{3}{c}{ Mean } \\
\hline & Highest 50\% & Lowest 50\% & Highest 50\% & Lowest 50\% \\
& GLEV & GLEV & & GLEV & GLEV \\
\cline { 2 - 7 } BANK & 0.2019 & 0.0336 & $(8.818)^{* * *}$ & 0.2672 & 0.1580 & $(8.001)^{* * *}$ \\
INT & 0.0897 & 0.2434 & $(7.273)^{* * *}$ & 0.1826 & 0.3172 & $(8.726)^{* * *}$ \\
LEV & 0.7265 & 0.6014 & $(8.346)^{* * *}$ & 0.6834 & 0.5780 & $(8.806)^{* * *}$ \\
\hline
\end{tabular}


Table 4

Determinants of bank debt concentration

This table shows results of Tobit regressions (censored normal) of the determinants of bank debt concentration (i.e. the bank debt to total liabilities ratio, BANK) for the 553 companies in the stand-alone sample, the 553 companies in the group sample and the 1,106 companies in the combined (full) sample. LEV, GLEV and GRES are residuals from auxiliary OLS regressions. GROUP is a dummy variable (value of 1 if a company is part of a business group, 0 otherwise). The other variables are defined in Table 2. Huber-White robust standard errors are reported in parentheses. ${ }^{* *}$ denotes significance at the $1 \%$ level; ** denotes significance at the $5 \%$ level; * denotes significance at the $10 \%$ level.

\begin{tabular}{|c|c|c|c|c|c|c|c|}
\hline & Stand-alone & \multicolumn{5}{|c|}{ Group Sample } & \multirow{2}{*}{$\begin{array}{c}\begin{array}{c}\text { Full } \\
\text { Sample }\end{array} \\
\text { E }\end{array}$} \\
\hline & $\mathrm{A}$ & $\mathrm{B}$ & $\mathrm{C}$ & $\mathrm{D}$ & $C^{\prime}$ & $\mathrm{D}^{\prime}$ & \\
\hline ROA & $\begin{array}{c}-0.3197^{* * *} \\
(0.082)\end{array}$ & $\begin{array}{c}-0.3062^{* * *} \\
(0.046)\end{array}$ & $\begin{array}{r}-0.1807 \\
(0.117)\end{array}$ & $\begin{array}{c}-0.2225^{*} \\
(0.122)\end{array}$ & $\begin{array}{r}-0.0921 \\
(0.122)\end{array}$ & $\begin{array}{r}-0.1089 \\
(0.122)\end{array}$ & $\begin{array}{c}-0.3370^{* * *} \\
(0.072)\end{array}$ \\
\hline TANG & $\begin{array}{c}0.5235^{\star * *} \\
(0.029)\end{array}$ & $\begin{array}{c}0.3969^{* * *} \\
(0.046)\end{array}$ & $\begin{array}{c}0.4144^{* * *} \\
(0.041)\end{array}$ & $\begin{array}{c}0.4135^{* * *} \\
(0.045)\end{array}$ & $\begin{array}{c}0.4714^{* * *} \\
(0.048)\end{array}$ & $\begin{array}{c}0.4667^{* * *} \\
(0.049)\end{array}$ & $\begin{array}{c}0.4779 * * * \\
(0.027)\end{array}$ \\
\hline SIZE & $\begin{array}{c}0.0244^{* *} \\
(0.011)\end{array}$ & $\begin{array}{c}0.0396^{* * *} \\
(0.008)\end{array}$ & $\begin{array}{c}0.0514^{* * *} \\
(0.009)\end{array}$ & $\begin{array}{c}0.0569 * * * \\
(0.009)\end{array}$ & $\begin{array}{c}0.0518^{* * *} \\
(0.009)\end{array}$ & $\begin{array}{c}0.0529 * * * \\
(0.009)\end{array}$ & $\begin{array}{c}0.0352^{* * *} \\
(0.007)\end{array}$ \\
\hline AGE & $\begin{array}{c}-0.0189 * * \\
(0.008)\end{array}$ & $\begin{array}{r}-0.0054 \\
(0.012)\end{array}$ & $\begin{array}{r}-0.0001 \\
(0.011)\end{array}$ & $\begin{array}{l}0.0002 \\
(0.012)\end{array}$ & $\begin{array}{l}0.0001 \\
(0.010)\end{array}$ & $\begin{array}{r}-0.0006 \\
(0.012)\end{array}$ & $\begin{array}{r}-0.0084 \\
(0.008)\end{array}$ \\
\hline GROWTH & $\begin{array}{r}-0.0257 \\
(0.034)\end{array}$ & $\begin{array}{l}0.0198 \\
(0.048)\end{array}$ & $\begin{array}{l}0.0021 \\
(0.048)\end{array}$ & $\begin{array}{r}-0.0145 \\
(0.047)\end{array}$ & $\begin{array}{r}-0.0169 \\
(0.041)\end{array}$ & $\begin{array}{r}-0.0119 \\
(0.041)\end{array}$ & $\begin{array}{r}-0.0134 \\
(0.031)\end{array}$ \\
\hline LEV & $\begin{array}{c}0.4857^{* * *} \\
(0.029)\end{array}$ & $\begin{array}{c}0.3662^{* * *} \\
(0.049)\end{array}$ & $\begin{array}{c}0.1917^{* * *} \\
(0.049)\end{array}$ & $\begin{array}{c}0.2769 * * * \\
(0.049)\end{array}$ & $\begin{array}{c}0.2462^{* * *} \\
(0.054)\end{array}$ & $\begin{array}{c}0.2885^{* * *} \\
(0.054)\end{array}$ & $\begin{array}{c}0.4452^{* * *} \\
(0.029)\end{array}$ \\
\hline GROUP & - & - & - & - & - & - & $\begin{array}{c}-0.0445^{\star * *} \\
(0.012)\end{array}$ \\
\hline GSIZE & - & - & $\begin{array}{c}-0.0399 * * * \\
(0.008)\end{array}$ & $\begin{array}{c}-0.0432^{* * *} \\
(0.009)\end{array}$ & $\begin{array}{c}-0.0531^{* * *} \\
(0.014)\end{array}$ & $\begin{array}{c}-0.0540^{* * *} \\
(0.014)\end{array}$ & - \\
\hline GAGE & - & - & $\begin{array}{c}-0.0260^{* * *} \\
(0.009)\end{array}$ & $\begin{array}{c}-0.0252^{* * *} \\
(0.009)\end{array}$ & - & - & - \\
\hline GROA & - & - & $\begin{array}{r}-0.1832 \\
(0.191)\end{array}$ & $\begin{array}{r}-0.1468 \\
(0.193)\end{array}$ & $\begin{array}{r}-0.0934 \\
(0.210)\end{array}$ & $\begin{array}{r}-0.0666 \\
(0.209)\end{array}$ & - \\
\hline GLEV & - & - & $\begin{array}{c}0.5196^{* * *} \\
(0.061)\end{array}$ & - & $\begin{array}{c}0.3947^{* * *} \\
(0.094)\end{array}$ & - & - \\
\hline GRES & - & - & - & $\begin{array}{c}-0.3874^{* * *} \\
(0.067)\end{array}$ & 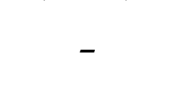 & $\begin{array}{c}-0.2021^{* *} \\
(0.094)\end{array}$ & - \\
\hline Intercept & $\begin{array}{r}-0.1387 \\
(0.101)\end{array}$ & $\begin{array}{c}-0.4653^{* * *} \\
(0.109)\end{array}$ & $\begin{array}{r}-0.0367 \\
(0.138)\end{array}$ & $\begin{array}{r}-0.0516 \\
(0.125)\end{array}$ & $\begin{array}{l}0.1199 \\
(0.214)\end{array}$ & $\begin{array}{l}0.1146 \\
(0.211)\end{array}$ & $\begin{array}{c}-0.3060 * * * \\
(0.075)\end{array}$ \\
\hline $\begin{array}{l}\text { Industry \& time } \\
\text { dummies }\end{array}$ & Yes & Yes & Yes & Yes & Yes & Yes & Yes \\
\hline $\begin{array}{l}\text { Group-specific } \\
\text { dummies }\end{array}$ & - & No & No & No & Yes & Yes & No \\
\hline Log likelihood & -113.5583 & -378.0689 & -320.5819 & -340.4964 & -105.4033 & -114.0218 & -562.2786 \\
\hline Adj. $R^{2}$ & 0.3192 & 0.1922 & 0.2452 & 0.2276 & 0.4061 & 0.3928 & 0.2441 \\
\hline
\end{tabular}


Table 5

Determinants of internal debt concentration

This table shows results of Tobit regressions (censored normal) of the determinants of internal debt concentration (i.e. the internal debt to total liabilities ratio, INT) for the 553 companies in the group sample. LEV, GLEV and GRES are residuals from auxiliary OLS regressions. The other variables are defined in Table 2. Huber-White robust standard errors are reported in parentheses. ${ }^{* * *}$ denotes significance at the $1 \%$ level; ** denotes significance at the $5 \%$ level; * denotes significance at the $10 \%$ level.

\begin{tabular}{|c|c|c|c|c|c|}
\hline & $\mathrm{F}$ & G & $\mathrm{H}$ & $\mathrm{G}^{\prime}$ & $\mathrm{H}^{\prime}$ \\
\hline ROA & $\begin{array}{c}-0.5769^{* * *} \\
(0.109)\end{array}$ & $\begin{array}{c}-0.6773^{* * *} \\
(0.114)\end{array}$ & $\begin{array}{c}-0.6650^{* * *} \\
(0.113)\end{array}$ & $\begin{array}{c}-0.6309^{* * *} \\
(0.104)\end{array}$ & $\begin{array}{c}-0.6205^{* * *} \\
(0.104)\end{array}$ \\
\hline TANG & $\begin{array}{r}-0.0207 \\
(0.046)\end{array}$ & $\begin{array}{r}-0.0296 \\
(0.044)\end{array}$ & $\begin{array}{c}-0.0306 \\
(0.046)\end{array}$ & $\begin{array}{r}-0.0292 \\
(0.047)\end{array}$ & $\begin{array}{r}-0.0256 \\
(0.047)\end{array}$ \\
\hline SIZE & $\begin{array}{c}0.0227^{* *} \\
(0.009)\end{array}$ & $\begin{array}{l}0.0129 \\
(0.009)\end{array}$ & $\begin{array}{l}0.0077 \\
(0.009)\end{array}$ & $\begin{array}{l}0.0005 \\
(0.008)\end{array}$ & $\begin{array}{r}-0.0009 \\
(0.008)\end{array}$ \\
\hline AGE & $\begin{array}{c}-0.0243^{* *} \\
(0.012)\end{array}$ & $\begin{array}{c}-0.0296^{* * *} \\
(0.011)\end{array}$ & $\begin{array}{c}-0.0262^{* *} \\
(0.012)\end{array}$ & $\begin{array}{c}-0.0219 * \\
(0.012)\end{array}$ & $\begin{array}{c}-0.0208^{*} \\
(0.013)\end{array}$ \\
\hline GROWTH & $\begin{array}{l}0.0787 \\
(0.051)\end{array}$ & $\begin{array}{l}0.0243 \\
(0.050)\end{array}$ & $\begin{array}{l}0.0784 \\
(0.051)\end{array}$ & $\begin{array}{c}0.1063^{* *} \\
(0.043)\end{array}$ & $\begin{array}{c}0.1018^{* *} \\
(0.044)\end{array}$ \\
\hline LEV & $\begin{array}{c}0.2316^{* * *} \\
(0.047)\end{array}$ & $\begin{array}{c}0.3459 * * * \\
(0.049)\end{array}$ & $\begin{array}{c}0.2710^{* * *} \\
(0.048)\end{array}$ & $\begin{array}{c}0.2781^{* * *} \\
(0.049)\end{array}$ & $\begin{array}{c}0.2455^{* * *} \\
(0.051)\end{array}$ \\
\hline GSIZE & - & $\begin{array}{c}0.0365^{* * *} \\
(0.008)\end{array}$ & $\begin{array}{c}0.0399 * * * \\
(0.009)\end{array}$ & $\begin{array}{c}0.0564^{* * *} \\
(0.016)\end{array}$ & $\begin{array}{c}0.0573^{* * *} \\
(0.016)\end{array}$ \\
\hline GAGE & - & $\begin{array}{c}0.0290 * * * \\
(0.009)\end{array}$ & $\begin{array}{c}0.0315^{\star * *} \\
(0.009)\end{array}$ & $1,-2+1$ & 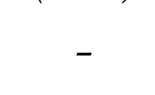 \\
\hline GROA & - & $\begin{array}{c}0.2956 \\
(0.193)\end{array}$ & $\begin{array}{c}0.2604 \\
(0.196)\end{array}$ & $\begin{array}{c}0.6207^{* * *} \\
(0.210)\end{array}$ & $\begin{array}{c}0.5912^{* * *} \\
(0.216)\end{array}$ \\
\hline GLEV & - & $\begin{array}{c}-0.4329 * * * \\
(0.065)\end{array}$ & - & $\begin{array}{c}-0.3336^{* * *} \\
(0.097)\end{array}$ & - \\
\hline GRES & - & r & $\begin{array}{c}0.1632^{* *} \\
(0.068)\end{array}$ & 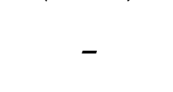 & $\begin{array}{l}0.1406 \\
(0.102)\end{array}$ \\
\hline Intercept & $\begin{array}{l}0.0315 \\
(0.124)\end{array}$ & $\begin{array}{c}-0.4236 * * * \\
(0.156)\end{array}$ & $\begin{array}{c}-0.4392^{* * *} \\
(0.158)\end{array}$ & $\begin{array}{c}-0.4119 * \\
(0.237)\end{array}$ & $\begin{array}{c}-0.4115^{*} \\
(0.236)\end{array}$ \\
\hline $\begin{array}{l}\text { Industry \& time } \\
\text { dummies }\end{array}$ & Yes & Yes & Yes & Yes & Yes \\
\hline $\begin{array}{l}\text { Group-specific } \\
\text { dummies }\end{array}$ & No & No & No & Yes & Yes \\
\hline Log likelihood & -331.9372 & -286.1504 & -306.1002 & -2.8977 & -10.7354 \\
\hline Adj. $R^{2}$ & 0.1308 & 0.2119 & 0.1750 & 0.4384 & 0.4294 \\
\hline
\end{tabular}


Table 6

Simultaneous determination of bank and internal debt concentration

This table shows results of 2SLS simultaneous equations estimates of the determinants of of bank debt concentration (i.e. the bank debt to total liabilities ratio, BANK) and internal debt concentration (i.e. the internal debt to total liabilities ratio, INT) for the 553 companies in the group sample. LEV and GLEV are residuals from auxiliary OLS regressions. The other variables are defined in Table 2. Standard errors are reported in parentheses. ${ }^{* * *}$ denotes significance at the $1 \%$ level; ** denotes significance at the $5 \%$ level; * denotes significance at the $10 \%$ level.

\begin{tabular}{|c|c|c|c|c|}
\hline & \multicolumn{2}{|c|}{ System I } & \multicolumn{2}{|c|}{ System II } \\
\hline & BANK & INT & BANK & INT \\
\hline ROA & $\begin{array}{c}-0.4676^{* * *} \\
(0.163)\end{array}$ & $\begin{array}{c}-0.5014^{* * *} \\
(0.088)\end{array}$ & $\begin{array}{c}-0.2864^{* *} \\
(0.133)\end{array}$ & $\begin{array}{c}-0.5285^{* * *} \\
(0.087)\end{array}$ \\
\hline TANG & $\begin{array}{c}0.2828^{* * *} \\
(0.034)\end{array}$ & - & $\begin{array}{c}0.3196^{* * *} \\
(0.034)\end{array}$ & 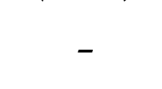 \\
\hline SIZE & $\begin{array}{c}0.0327^{* * *} \\
(0.007)\end{array}$ & $\begin{array}{l}0.0098 \\
(0.008)\end{array}$ & $\begin{array}{c}0.0263^{* * *} \\
(0.007)\end{array}$ & $\begin{array}{l}-0.0026 \\
(0.007)\end{array}$ \\
\hline AGE & $\begin{array}{c}-0.0154 \\
(0.012)\end{array}$ & $\begin{array}{c}-0.0237^{* *} \\
(0.009)\end{array}$ & $\begin{array}{r}-0.0023 \\
(0.010)\end{array}$ & $\begin{array}{l}-0.0183^{*} \\
(0.009)\end{array}$ \\
\hline GROWTH & - & - & $\begin{array}{l}0.0235 \\
(0.040)\end{array}$ & $\begin{array}{c}0.0808^{* *} \\
(0.036)\end{array}$ \\
\hline LEV & $\begin{array}{c}0.3674^{* * *} \\
(0.095)\end{array}$ & $\begin{array}{c}0.3217^{* * *} \\
(0.042)\end{array}$ & $\begin{array}{c}0.3016^{* * *} \\
(0.071)\end{array}$ & $\begin{array}{c}0.2730^{* * *} \\
(0.042)\end{array}$ \\
\hline BANK & - & $\begin{array}{r}-0.1037 \\
(0.112)\end{array}$ & - & $\begin{array}{r}-0.1387 \\
(0.097)\end{array}$ \\
\hline INT & $\begin{array}{c}-0.7911^{* * *} \\
(0.281)\end{array}$ & - & $\begin{array}{c}-0.6754^{* * *} \\
(0.238)\end{array}$ & - \\
\hline GSIZE & $\begin{array}{l}0.0028 \\
(0.013)\end{array}$ & $\begin{array}{c}0.0323^{* * *} \\
(0.007)\end{array}$ & $\begin{array}{r}-0.0112 \\
(0.015)\end{array}$ & $\begin{array}{c}0.0431^{* * *} \\
(0.011)\end{array}$ \\
\hline GAGE & - & $\begin{array}{c}0.0222^{* * *} \\
(0.008)\end{array}$ & 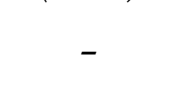 & ? \\
\hline GROA & - & - & - & $\begin{array}{c}0.5176^{* * *} \\
(0.170)\end{array}$ \\
\hline GLEV & $\begin{array}{r}-0.0113 \\
(0.130)\end{array}$ & $\begin{array}{c}-0.3952^{* * *} \\
(0.062)\end{array}$ & $\begin{array}{c}0.2403^{* * *} \\
(0.078)\end{array}$ & $\begin{array}{c}-0.1411^{*} \\
(0.075)\end{array}$ \\
\hline Intercept & $\begin{array}{r}-0.0318 \\
(0.129)\end{array}$ & $\begin{array}{c}-0.2758^{* *} \\
(0.112)\end{array}$ & $\begin{array}{l}0.1330 \\
(0.158)\end{array}$ & $\begin{array}{c}-0.1726 \\
(0.162)\end{array}$ \\
\hline $\begin{array}{l}\text { Industry \& time } \\
\text { dummies }\end{array}$ & Yes & Yes & Yes & Yes \\
\hline $\begin{array}{l}\text { Group-specific } \\
\text { dummies }\end{array}$ & No & No & Yes & Yes \\
\hline Adj. $R^{2}$ & 0.2210 & 0.2185 & 0.3932 & 0.4582 \\
\hline
\end{tabular}

